\title{
Productivity and quality, competition and facilitation of chicory in ryegrass/legume-based pastures under various nitrogen supply levels
}

\author{
Henning Høgh-Jensen ${ }^{\mathrm{a}, *}$, Bea Nielsen ${ }^{\mathrm{b}}$, Stig Milan Thamsborg ${ }^{\mathrm{c}}$ \\ a Department of Agricultural Sciences, Royal Veterinary and Agricultural University, Højbakkegaard Allé 9, 2630 Taastrup, Denmark \\ ${ }^{\mathrm{b}}$ Department of Animal Science and Animal Health, Royal Veterinary and Agricultural University, Grønnegaardsvej 2, 1870 Frederiksberg C, Denmark \\ ${ }^{\mathrm{c}}$ Department of Pathobiology, Royal Veterinary and Agricultural University, Dyrlagevej 100, 1870 Frederiksberg C, Denmark
}

Received 1 May 2005; received in revised form 28 September 2005; accepted 24 October 2005

\begin{abstract}
Traditional perennial ryegrass-white clover mixtures have limitations in combined productivity and quality that herbs like chicory may alleviate. This study examined the consequences on productivity and quality of as well as competition and facilitation after introducing chicory into varies ryegrass-legume-based pastures in a field study over three consecutive growing seasons. A cultivar of chicory, suitable for grazing, in pure stand was found to out-yield a pure stand ryegrass in terms of dry matter and nitrogen $(\mathrm{N})$ accumulation but was found to yield similar to mixtures of chicory and ryegrass. The inclusion of chicory, increased $\mathrm{N}$ accumulation per area unit irrespective of associated leguminous species but had no effect $(P>0.05)$ on the combined dry matter yield of these mixtures as compared to the chicory-ryegrass mixture. Chicory was not found to co-exist well with associated fodder legumes but it co-existed well with perennial ryegrass. Determined by a direct ${ }^{15} \mathrm{~N}$ plant labelling technique, chicory transferred little $\mathrm{N}$ to associated legumes and under moderate soil $\mathrm{N}$ conditions it almost out-competed the white clover whereas lucerne was able to withstand the competition with birdsfoot trefoil as intermediate. Chicory and ryegrass did exchange $\mathrm{N}$ amounting to less than $5 \%$ of the receiver plants' $\mathrm{N}$ economy whereas the $\mathrm{N}$ transfer from the $\mathrm{N}$-rich lucerne constituted $15 \%$ of the associated ryegrass' $\mathrm{N}$ economy but less $(P<0.05)$ of the chicory's $\mathrm{N}$ economy. These differences are ascribed to the species' root morphology and root zonation. Chicory accumulated large amounts of calcium, potassium, sodium and zinc but significant less of magnesium and manganese, irrespective of the $\mathrm{N}$ supply. In the case of sodium it was a short-term effect whereas calcium and possibly also sulphur, copper and zinc accumulation increased over time. It is concluded that chicory may improve the management of intensive dairy farms with a large $\mathrm{N}$ surplus because of the increase in productivity per unit area and $\mathrm{N}$ uptake efficiency and add significant improvements of the quality of the forage.
\end{abstract}

(C) 2005 Elsevier B.V. All rights reserved.

Keywords: Chicory; Grassland mixtures; Pastures; Quality; Productivity; Nitrogen management

\section{Introduction}

Forage is an important and indispensable part of livestock systems in Europe. Traditionally these forages have been based on perennial ryegrass-white clover mixtures (Boller and Nösberger, 1987; Frame and Newbould, 1986; Høgh-Jensen and Schjoerring, 1994; Lantinga et al., 2004). However a limitation of the white clover-based swards is the intensive but short growth period of white clover compared to other grassland species which are leading to management problems. The early summer protein content of the sward for example is higher and the fibre content is lower than the level required by the grazing animal which leads to an unbalance in the ruminal microbial

\footnotetext{
* Corresponding author. Tel.: +45 35283391; fax: +45 35283384.

E-mail address: hhj[a]kvl.dk (H. Høgh-Jensen).
}

system and thus poor feed utilization and excess $\mathrm{N}$ disposal. This period is bordered by late spring growth of white clover as well as a slow late summer growth rate leading to a reduced content of clover in the silage cut early or late in the season. Furthermore, under intensive conditions white clover may be almost lost in the system, reducing such systems to contain one species only, i.e. ryegrass.

New systems are thus needed for the grassland-based sector to remain competitive. Such systems could be based on new adopted species that adds complementary functionalities to the grasslands like added protein and minerals in periods where white clover do not supply these. Further the species should still have a high productivity, a good digestibility and palatability to remain a species favoured by the animals.

Chicory (Chicorium intybus) is a tap-rooted semi-perennial herb of the family Asteraceae with a rosette growth habit (Rumball, 1986). It is native to Europe, Western and Central 
Asia, North Africa and South America and is after intensive breeding efforts gaining popularity in grassland due to its high forage quality and productivity (Barry, 1998; Belesky et al., 2001; Collins and McCoy, 1997).

Due to such forage qualities it could potential play an important role in livestock production systems because of an improved supply of protein, natural minerals and vitamins in the sward. It growth patterns complement that of perennial ryegrass and favourable growth has been found in animals grazing chicory as compared to grasses (Barry, 1998; Fraser and Rowarth, 1996; Komolong et al., 1992; Turner et al., 1999).

Several experiments have shown that chicory has a high content of sodium, zinc, copper, iron, calcium, magnesium and sulphur compared to ryegrass and lucerne (Belesky et al., 1999; Crush and Evans, 1990; Jung et al., 1996). Thus, chicory in a grass mixture may have the potential to improve the supply of microminerals in the diet. However knowledge is lacking regarding the productivity of chicory in varying grassland mixtures under European conditions and how the species composition affects the quality of the individual species in the mixtures.

The objectives of this study were to examine the consequences on productivity and quality of as well as competition and facilitation after introducing chicory into a variety fodder legume/ryegrass-based pastures over three consecutive years under varying $\mathrm{N}$ supply, including the use and transfer of available $\mathrm{N}$. The superior grassland fodder legumes of lucerne, birdsfoot trefoil, and white clover were tested (Frame et al., 1998).

The four species were chosen due to the expected complementary resource uses of the investigated species, legume versus non-legume and shallow-rooted grass versus deep-rooted herb. It was hypothesised that the $\mathrm{N}$ supply level would favour ryegrass on the expense of chicory. Further, due to the legumes unrestricted access to atmospheric $\mathrm{N}$ they were expected to have a major advantage under the relative low-input conditions.

\section{Materials and methods}

The experimental area was located $18 \mathrm{~km}$ west of Copenhagen $\left(55^{\circ} 40^{\prime} \mathrm{N}, 12^{\circ} 18^{\prime} \mathrm{E} ; 28 \mathrm{~m}\right.$ above m.s.l.) on a fertile sandy loam, classified as Typic Hapludalf, with a pre-history of cropping mainly cereals under recommended applications of phosphorus and potassium. The 30-year average for annual precipitation and annual mean air temperature were $600 \mathrm{~mm}$ and $7.6^{\circ} \mathrm{C}$, respectively, with maximum and minimum daily air temperature of $15.8^{\circ} \mathrm{C}$ (July) and $-0.9^{\circ} \mathrm{C}$ (February).

The soil $\mathrm{pH}_{\left(0.01 \mathrm{MCaCl}_{2}\right)}$ was 5.1. The total contents of $\mathrm{N}$ in the $0-20 \mathrm{~cm}$ of the soil was $0.133 \%$ with a C:N ratio of 9 . The soil had $14.9 \%, 18.1 \%, 36.2 \%$, and $30.8 \%$ clay, silt, fine and coarse sand, respectively, as determined by the hydrometer method (Gee and Bauder, 1986).

\subsection{Establishing the plant communities and experimental treatments}

The randomised factorial experimental design with four replicates consisted of two fertilizer treatments $(0$ or
$120 \mathrm{~kg} \mathrm{Nha}^{-1}$ year $^{-1}$ ) of the eight crops applied in split doses applied early spring and again after defoliation. However, only $90 \mathrm{~kg} \mathrm{Nha}^{-1}$ year $^{-1}$ was applied to the fertilizer plots the first production year.

The experimental plant communities were established in spring 2001. The communities were perennial ryegrass (Lolium perenne $\mathrm{L} . \mathrm{cv}$. Mikado) in pure stand, chicory (C. intybus $\mathrm{L}$. cv. Grassland Puna) in pure stand, ryegrass-chicory mixture, ryegrass-white clover (Trifolium repens $\mathrm{L}$. cv. Milo) mixture, ryegrass-chicory-lucerne (Medicago sativa L. cv. Blue Vela) mixture, ryegrass-chicory-birdsfoot trefoil (Lotus corniculatus L. cv. Grasslands Goldie) mixture, and ryegrass-chicory-white clover mixture.

Each plot was $6.5 \mathrm{~m}^{2}$. The seeding rates were always 20 and $10 \mathrm{~kg} \mathrm{ha}^{-1}$ for ryegrass and chicory, respectively, both in pure stand and in mixture. White clover and birdsfoot trefoil were seeded with $8 \mathrm{~kg} \mathrm{ha}^{-1}$ and lucerne with $30 \mathrm{~kg} \mathrm{ha}^{-1}$.

During the first year, cuttings were done on 31 August, 6 September, and 1 November, during the second year on 15 May, 18 June, 7 August, and 16 October, and during the third year on 7 June, 7 August, and 13 October, according to herbage accumulation to simulate a classical cut-and-carry strategy under Danish conditions.

\section{2. ${ }^{15}$ N labelling}

During early spring 2004, in part of some unfertilised plots of the mixtures of ryegrass-chicory and ryegrass-chicory-lucerne, PVC cylinders (mezotrons) with an internal diameter of $29.7 \mathrm{~cm}$ were inserted $60 \mathrm{~cm}$ into the ground leaving $5 \mathrm{~cm}$ of the cylinder above the soil surface. The only other disturbance during the experimental period was the application of ${ }^{15} \mathrm{~N}$ as described below and sampling of the shoot material.

The plants in the mezotrons were leaf-labelled during the early growing season, its third, as follows: one clover or lucerne leaf or several grass leaves were inserted into 5-ml vials containing $2.0 \mathrm{ml}$ of a $1.0 \%(\mathrm{v} / \mathrm{v})$ highly ${ }^{15} \mathrm{~N}$ enriched (99 at.\%) urea solution (described in details in Høgh-Jensen and Schjoerring, 2000). The vials were thereafter sealed using an inert plastic material (Terostat, Henkel Surface Technologies, Gulph Mills, Pennsylvania, USA). The leaves were enclosed in the vials between 2 and 5 days, depending on climatic conditions (i.e. potential evapotranspiration). The ${ }^{15} \mathrm{~N}$ urea was offered from nine vials in each mezotrons. After the labelling period, the vials were removed but the recovered quantity of ${ }^{15} \mathrm{~N}$ was not determined as the aim just was to ensure the labelled plant achieved sufficient ${ }^{15} \mathrm{~N}$ enrichment.

Adjacent to the mezotrons, $2 \mathrm{~m}^{2}$ plots of the plant communities were labelled with ${ }^{15} \mathrm{~N}$ fertiliser $\left[\left(\mathrm{NH}_{4}\right)_{2} \mathrm{SO}_{4} ; 99\right.$ at.\%; equivalent to $0.10 \mathrm{~g} \mathrm{~N} \mathrm{~m}^{-2}$ ]. Prior to application the ${ }^{15} \mathrm{~N}$ fertiliser was dissolved in de-ionised water, mixed thoroughly with glucose (C:N ratio of 8 ), and sprayed onto the soil surface between the plants at the 15 April 2004, which was a rainy day, before the soil temperature in $10 \mathrm{~cm}$ depth exceeded $4{ }^{\circ} \mathrm{C}$.

The symbiotic $\mathrm{N}_{2}$-fixation and the competition for soil $\mathrm{N}$ were determined in these plots using ${ }^{15} \mathrm{~N}$ isotope dilution (as 
described in details by Høgh-Jensen and Schjoerring, 1994), using ryegrass in mixture as the reference.

\subsection{Sampling and analysis}

Total yield was estimated by cutting with a Haldrup harvester equipped with an electronic balance. A representative sub-sample was extracted of which the dry matter content was determined. The harvester was leaving a stubble height of $5 \mathrm{~cm}$. Before this sampling, at all cutting occasions and at all treatments, the central $1 \mathrm{~m}^{2}$ of the plot was handcut with shears to a height of $5 \mathrm{~cm}$. The samples were separated into different botanical crops, dried to constant weight at $80^{\circ} \mathrm{C}$, ground in a Wiley mill (sieve mesh size of $2 \mathrm{~mm}$ ) and stored under dry and dark conditions.

The plant populations in mezotrons and in the plots were managed similarly to the ${ }^{15} \mathrm{~N}$ labelled plots. The plants were cut with hand shears, leaving plant stubbles of $5 \mathrm{~cm}$. The shoot biomass was then separated into its respective species, dried to constant weight at $80^{\circ} \mathrm{C}$, weighed, pulverised to a fine powder and analysed.

The ${ }^{15} \mathrm{~N}$ labelled plant material were analysed for total $\mathrm{N}$ and ${ }^{15} \mathrm{~N}$ using an ANCA-SL Elemental Analyser coupled to a 20-20 Tracermass Mass Spectrometer (Europa Scientific Ltd., Crewe, UK). The unlabelled plant material were analysed for total $\mathrm{N}$ content on an elemental analyser (ThermoQuest S.p.A., Milano, Italy).

Samples of the ryegrass-chicory mixtures from the first two growth seasons were pooled per sampling and analysed for calcium, magnesium, potassium, phosphorus, sulphur, sodium, cupper, manganese and zinc by inductively coupled plasma spectroscopy (Perkin Elmer Optima 4300 DV ICP-OES, Perkin Elmer Life And Analytical Sciences, Inc., Boston, MA, USA) after digestion in a micro oven.

\subsection{Calculations and statistical methods}

The fraction of $\mathrm{N}$ derived from the atmosphere in the harvested clover material (\% Ndfa) was calculated as (Peoples et al., 1989):

$\% \mathrm{Ndfa}=\left[\frac{\delta^{15} \mathrm{~N}_{\text {grass }}-\delta^{15} \mathrm{~N}_{\text {clover }}}{\delta^{15} \mathrm{~N}_{\text {grass }}-B}\right] \times 100$

where $\delta^{15} \mathrm{~N}$ is the ${ }^{15} \mathrm{~N}$ enrichment (\%o) relative to atmospheric $\mathrm{N}_{2}$. The $B$ value is the ${ }^{15} \mathrm{~N}$ enrichment (\%o), relative to atmospheric $\mathrm{N}_{2}$, of the legume grown solely on atmospheric $\mathrm{N}_{2}$. For clover a $B$ value of $-1.4 \delta^{15} \mathrm{~N}$ was used (Eriksen and HøghJensen, 1998) but the $B$ values was assumed to be nil for birdsfoot trefoil and lucerne.

Transfer of $\mathrm{N}$ was estimated, distinguishing between source plants and receiver plants as described by Høgh-Jensen and Schjoerring (2000).

An analysis of variance was carried out on the data using the GLM procedure of the SAS software (SAS Institute, 1993). Comparison of the means for the individual treatments was done using a Waller-Duncan $t$-test.

\section{Results}

\subsection{Dry matter and nitrogen accumulation}

The four mixtures including fodder legumes did not differ $(P>0.05)$ in average annual dry matter yield whether unfertilised or fertilised with moderate levels of $\mathrm{N}\left(120 \mathrm{~kg} \mathrm{Nha}^{-1} \mathrm{yr}^{-1}\right)$. The range of $\mathrm{N}$ management levels reflects typical $\mathrm{N}$ input levels in less intensive farms in Denmark. The botanical structure of multispecies mixtures is thus evaluated in this range. The inclusion of chicory into these mixtures had apparently no effect on the dry matter accumulation (Fig. 1A). However, chicory in pure stand
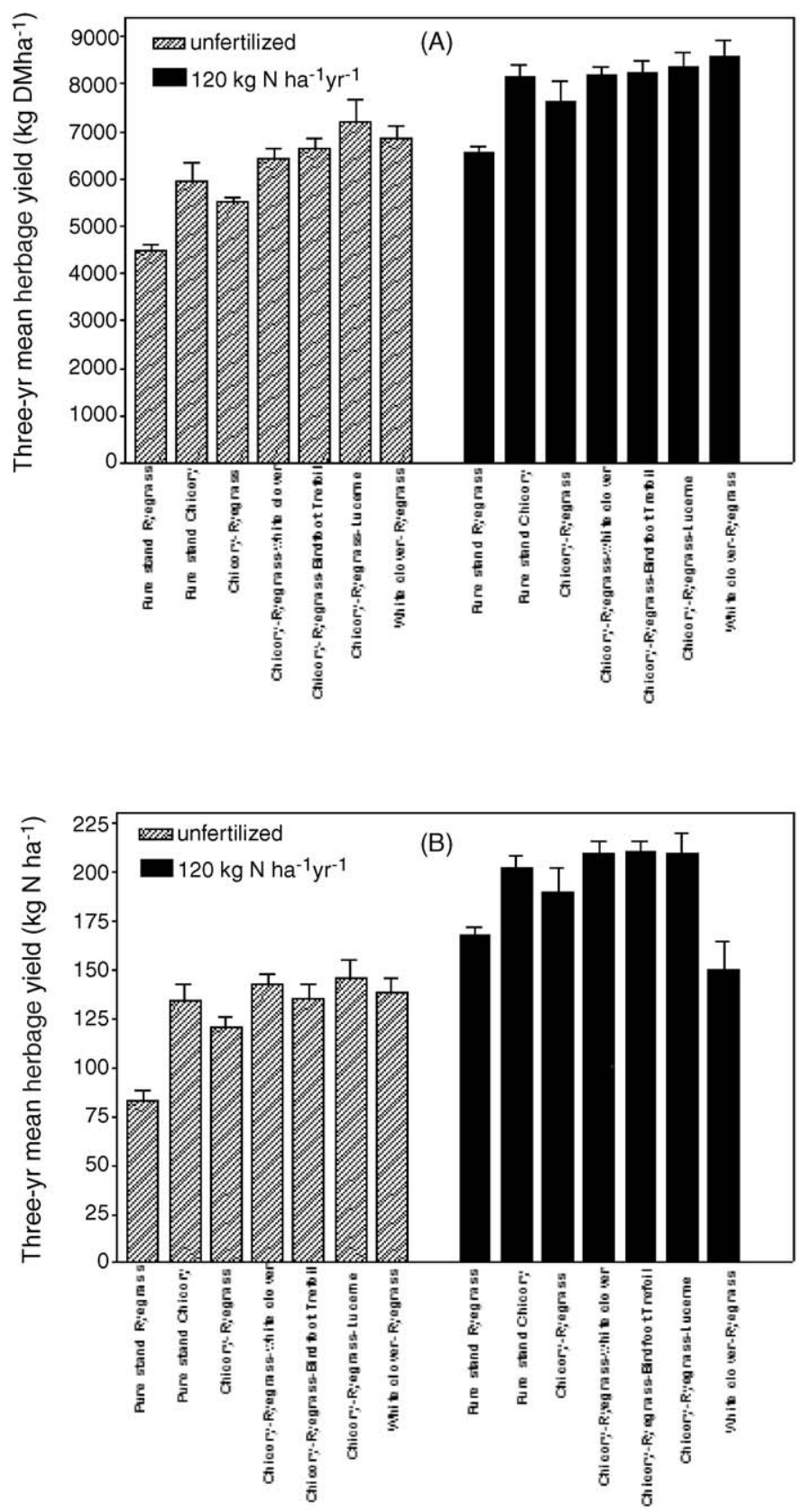

Fig. 1. Mean herbage yield (A) and nitrogen accumulation (B) of all species in the mixtures from three consecutive growing seasons. Mean \pm S.E. $(n=4)$. 
out-yielded $(P<0.05)$ perennial ryegrass irrespectively of the supply of fertilizer $\mathrm{N}$.

With the exception of ryegrass-white clover, the mixtures responded to the improved $\mathrm{N}$ supply by accumulating approx. $50 \mathrm{~kg} \mathrm{Nha}^{-1} \mathrm{yr}^{-1}$ (Fig. 1B). These tissue accumulations indicate that chicory used both the indigenous soil $\mathrm{N}$ and the fertilizer $\mathrm{N}$ pools very efficiently. Pure stands of chicory absorbed $35-50 \mathrm{~kg}$ more $\mathrm{N} \mathrm{ha}^{-1} \mathrm{yr}^{-1}$ than pure stands of perennial ryegrass (Fig. 1B).

\subsection{Utilisation of soil $N$}

The ${ }^{15} \mathrm{~N}$ was applied to the soil surface together with a carbon source (sucrose) that was expected to lead to a rapid incorporation of the ${ }^{15} \mathrm{~N}$ into the soil microbial biomass. This $\mathrm{N}$ was mainly utilised by perennial ryegrass and less by chicory both in ryegrass-chicory (Fig. 2A) and in ryegrass-chicory-lucerne (Fig. 2B). Lucerne absorbed less than $3 \%$ of the ${ }^{15} \mathrm{~N}$ that was applied to the mixture (Fig. 2B).

\subsection{Nutrients in the ryegrass-chicory mixture}

Chicory maintained a high concentration of calcium over the three growing seasons whereas ryegrass tended to decrease
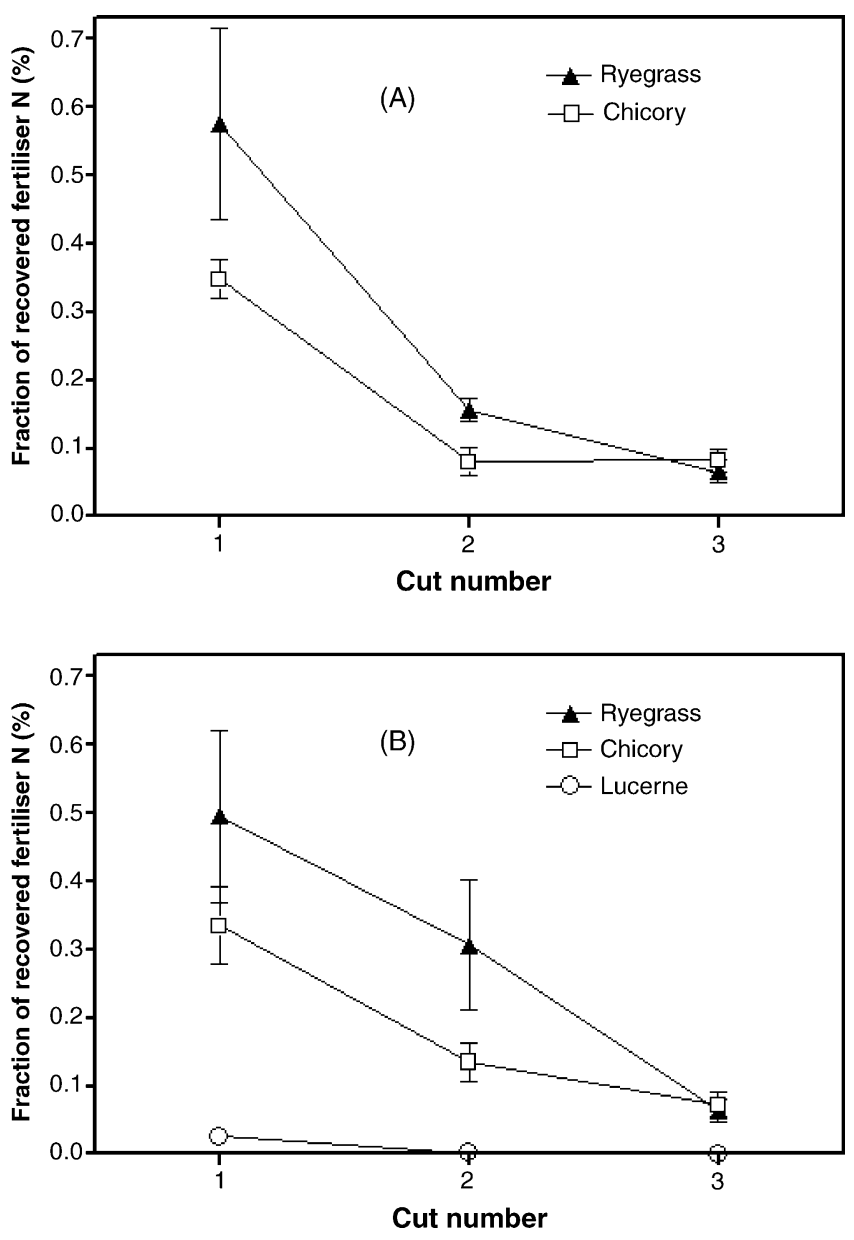

Fig. 2. Recovery of applied ${ }^{15} \mathrm{~N}$ to ryegrass-chicory (A) and ryegrass-chicorylucerne (B) mixtures in the third growing season. Mean \pm S.E. $(n=4)$.
(Fig. 3). The concentrations of magnesium, potassium, phosphorus, and sulphur in chicory and ryegrass differed only little over the 3 years although chicory tended to have higher concentrations of magnesium in particular. Chicory had significantly higher concentrations of sodium the first year but not the subsequent samplings. Chicory did contain higher concentrations of copper and zinc towards the end of the 3 years (Fig. 4) but ryegrass tended to contain higher concentrations of manganese through the 3 years.

When calculating the total accumulation of the nutrients, chicory accumulated significant higher amounts of calcium, potassium, sodium and zinc but significant less of magnesium and manganese (Fig. 5) irrespective of the $\mathrm{N}$ supply. The accumulations of phosphorus, sulphate and copper did not differ $(P>0.05)$.

\subsection{Exchange of nitrogen between species}

Following a pulse-labelling period of each species with ${ }^{15} \mathrm{~N}$, the exchange of $\mathrm{N}$ between the species in a mixture of dicotyledons were similar (Fig. 6A) but perennial ryegrass was the biggest donor in quantitative terms (Fig. 6B).

When labelling individual species in the triple mixture of perennial ryegrass, chicory, and lucerne, and calculating the importance for the receiver plant species, chicory contributed very little $(<5 \%)$ to the $\mathrm{N}$ economy of the associated ryegrass and lucerne (Fig. 7A). Lucerne contributed substantial to the $\mathrm{N}$ economy of ryegrass, $16 \%$ towards the end of the growth season, but much less to the $\mathrm{N}$ economy of chicory. In contrast, perennial ryegrass contributed substantial to the $\mathrm{N}$ economy of both chicory and lucerne, more than $16 \%$ towards the end of the growth season.

Using proportions of the receiver plants' $\mathrm{N}$ economy may lead to biased conclusions in a mixture with unequal proportions of each species but the asymmetric importance of each species as $\mathrm{N}$ donor to its associates is underlined when calculating the amounts of transferred $\mathrm{N}$. Over the season, chicory transferred approx. $350 \mathrm{mg} \mathrm{N}$ to the grass component but $1400 \mathrm{mg} \mathrm{N}$ to lucerne. Ryegrass contributed less than $100 \mathrm{mg} N$ to chicory but up to 100 times so much to lucerne. Lucerne contributed approx. $1100 \mathrm{mg} \mathrm{N}$ to chicory but twice so much to ryegrass (Fig. 7B). Thus, ryegrass and chicory had relatively little exchange of $\mathrm{N}$ not exceeding $5 \%$ of the receiver plant (Fig. 7A). The inclusion of a N-rich legume gave way of a high transfer of $\mathrm{N}$ from the legume to the ryegrass but not to the chicory (Fig. 7A).

\subsection{Competitive balance among the species under mowed management}

The species were defoliated three to four times during each growth season over the three seasons. Plotting the relative proportions of the sampled herbage as means over the defoliations will show any changes in the balance between species, i.e. the botanical structure. Under unfertilised conditions, the mean ryegrass proportion of the sampled herbage was for example $20 \%$, while chicory and lucerne constituted each $40 \%$ (Fig. 8). Generally, it is evident that ryegrass maintain a proportion of approx. 
$\mathrm{Ca}$
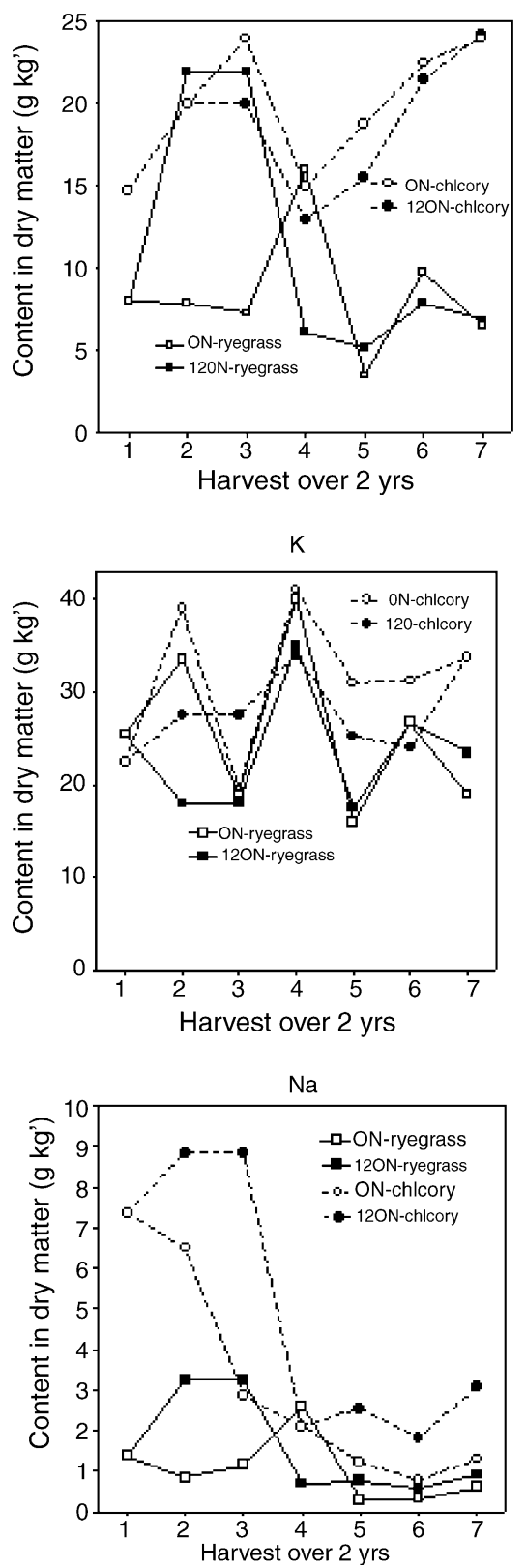

$\mathrm{Mg}$
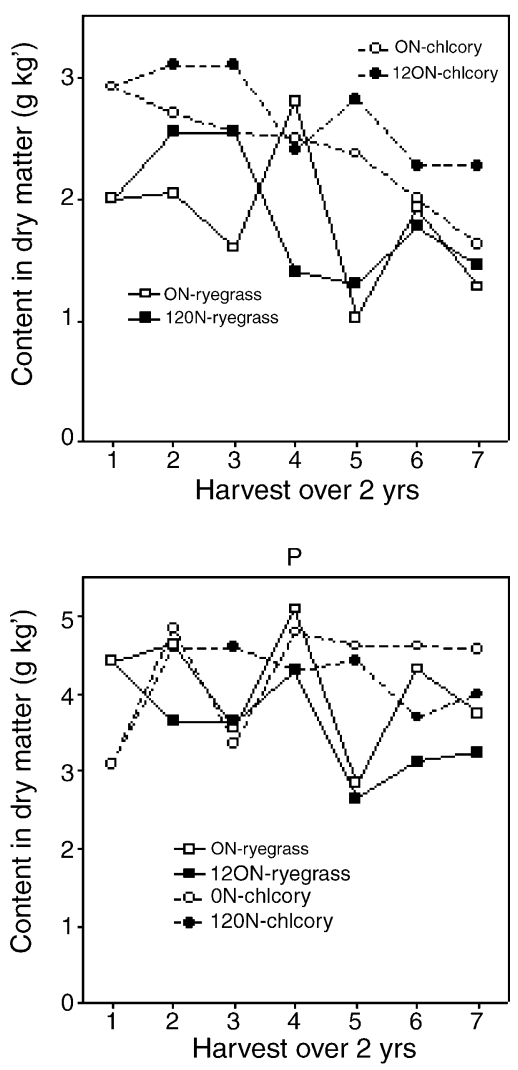

S

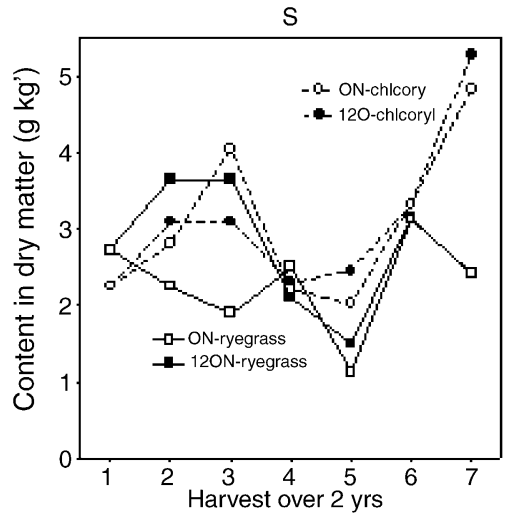

Fig. 3. Concentrations of macrominerals in the herbage of perennial ryegrass and chicory over three consecutive production years under zero or $120 \mathrm{~kg} \mathrm{Nha}^{-1} \mathrm{yr}^{-1}$. Mean \pm S.E. $(n=4)$.

$25 \%$ of the annual yield of herbage under unfertilised conditions and approx. $40 \%$ under a moderate supply of $\mathrm{N}$, i.e. $120 \mathrm{~kg} \mathrm{Nha}^{-1} \mathrm{yr}^{-1}$ based on dry matter yield as well as $\mathrm{N}$ accumulation (Fig. 8).

Chicory constituted $50 \%$ under a moderate supply of $\mathrm{N}$ but under unfertilised conditions, the proportion varied between $40 \%$ and $60 \%$ depending on the associated leguminous crop based on dry matter yield and almost similar when based on $\mathrm{N}$ accumulation, i.e. $35 \%$ and $65 \%$.

The legumes constituted around $10 \%$ when the sward received a moderate supply of $\mathrm{N}$, based on dry matter yield as well as $\mathrm{N}$ accumulation. However under unfertilised conditions, the legumes varied significantly, with lucerne constituting $40 \%$, birdsfoot trefoil $30 \%$ and $20 \%$ on a dry matter and $\mathrm{N}$ basis, respectively. White clover constituted around $15 \%$.

\section{Discussion}

The current studies attempted to answer the two questions formulated by Connolly et al. (2001), on which mixture is most productive, and what is the effect of one species' presence on the associated species performance. Due to the complementary resource uses of the investigated species, legume versus nonlegume and shallow-rooted grass versus deep-rooted herb, it was hypothesised that the $\mathrm{N}$ supply level would favour ryegrass on the expense of chicory. Further, due to the legumes unrestricted access to atmospheric $\mathrm{N}$ they were expected to have a 

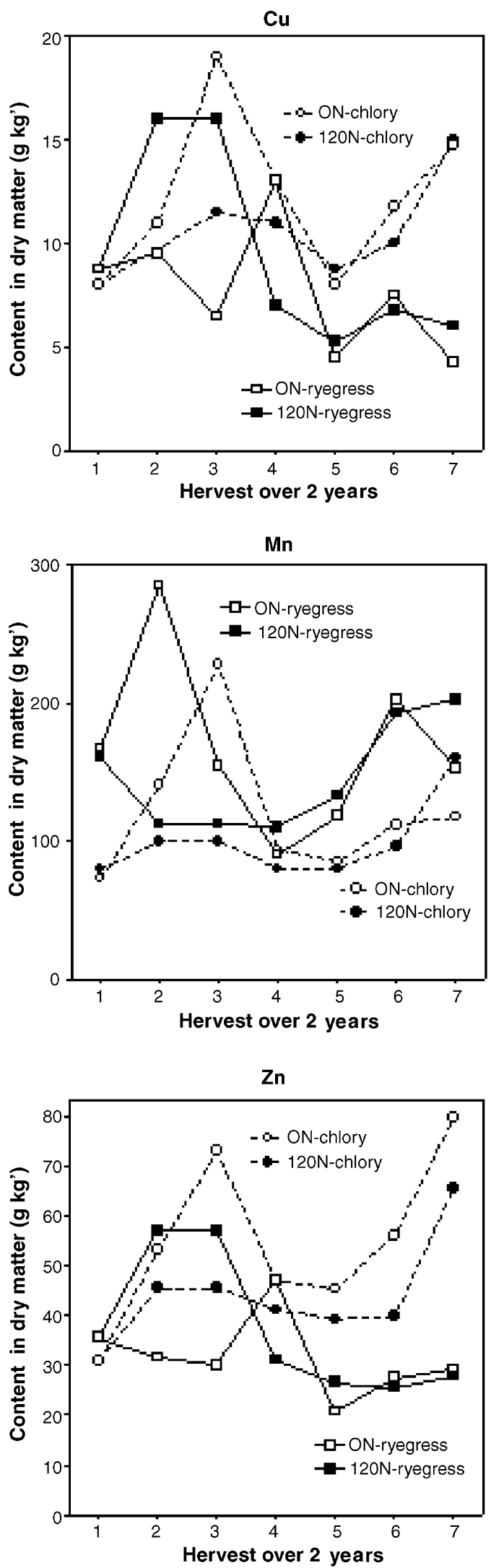

Fig. 4. Concentrations of microminerals in the herbage of perennial ryegrass and chicory over three consecutive production years under zero or $120 \mathrm{~kg} \mathrm{Nha}^{-1} \mathrm{yr}^{-1}$. Mean \pm S.E. $(n=4)$.

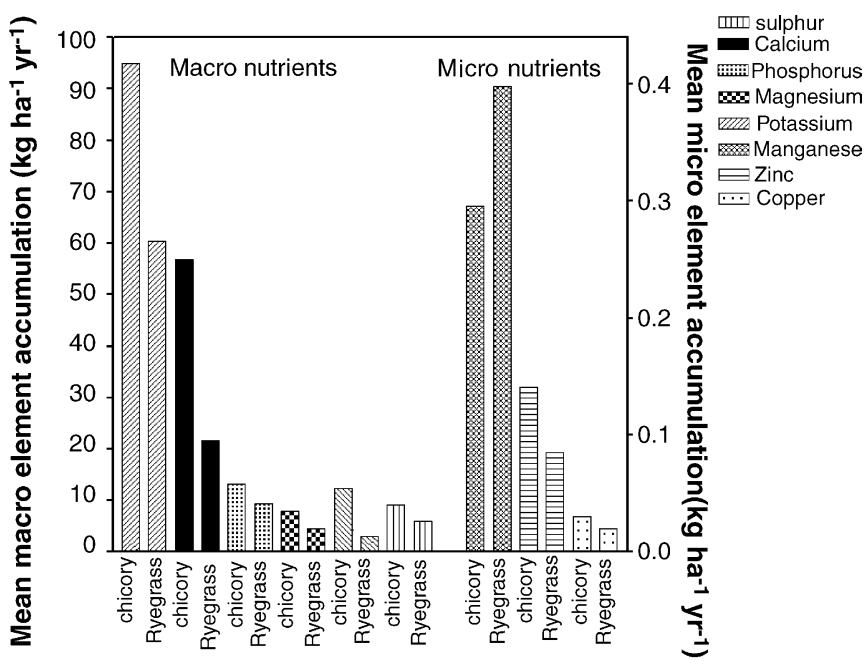

Fig. 5. Accumulations of macro- and microminerals in the herbage of perennial ryegrass and chicory over three consecutive production years averaged over $\mathrm{N}$ treatments as no significant difference.
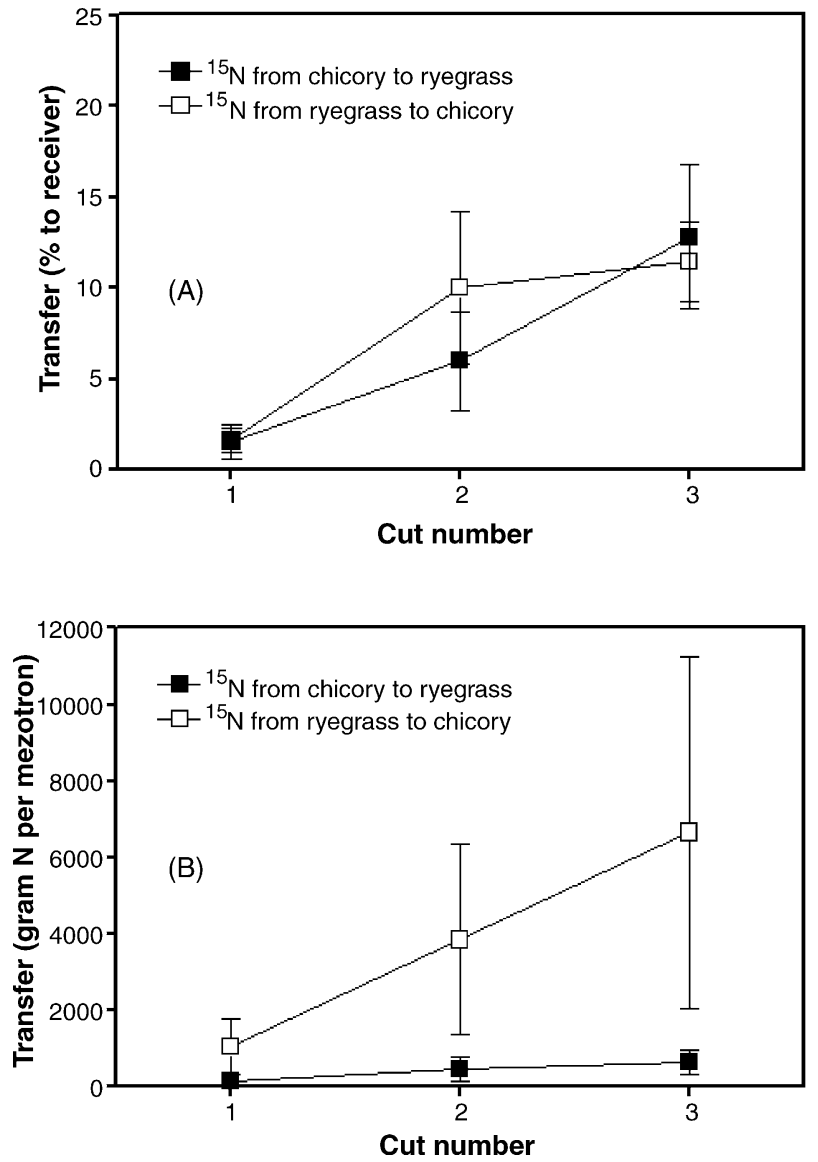

Fig. 6. Proportion of $\mathrm{N}$ transfer (A) and amount of $\mathrm{N}$ transfer (B) in the herbage of unfertilised perennial ryegrass and chicory in the third production years. Mean \pm S.E. $(n=4)$ 

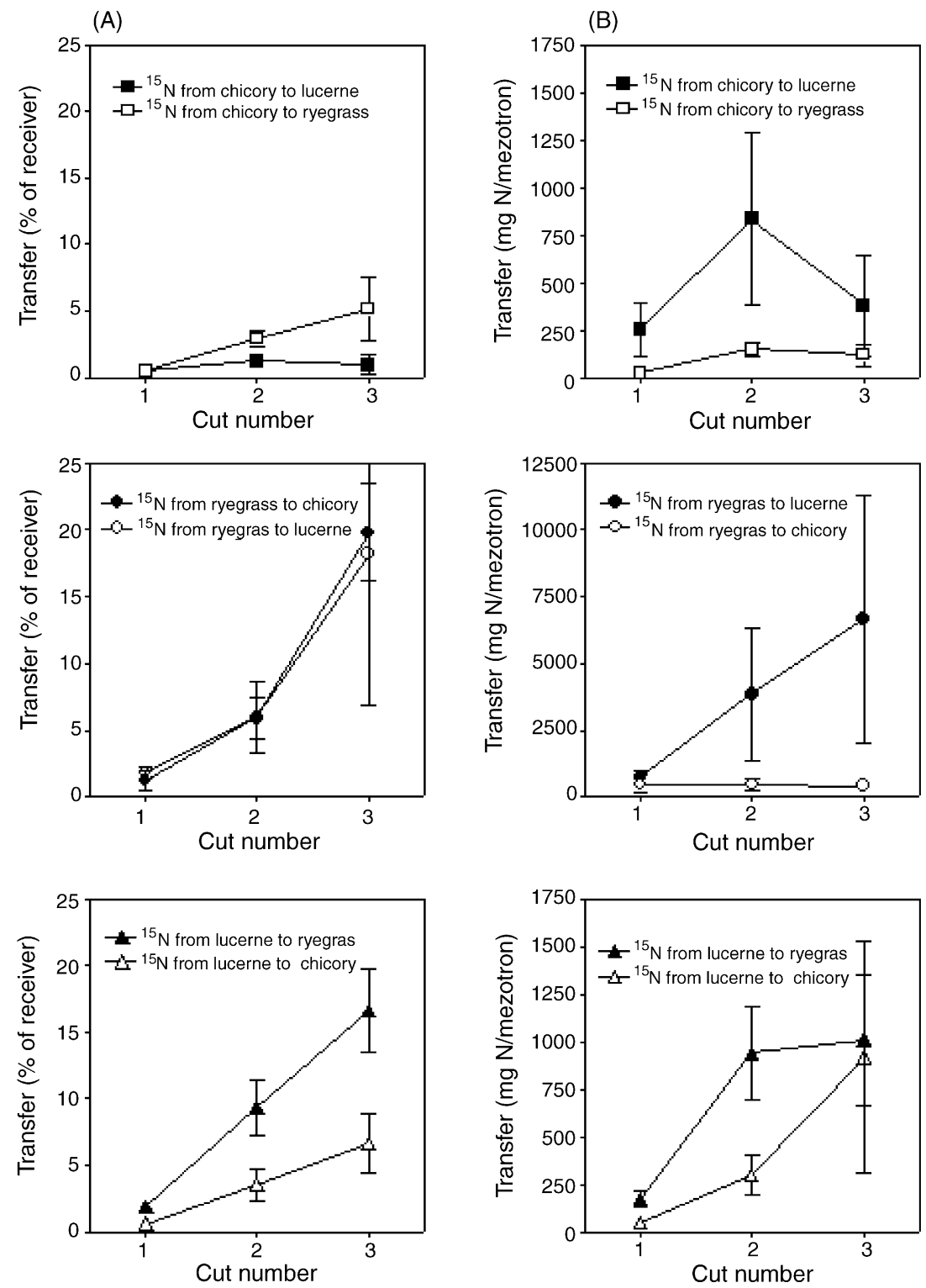

Fig. 7. Proportion of $\mathrm{N}$ transfer (A) and amount of $\mathrm{N}$ transfer (B) in the herbage of unfertilised perennial ryegrass, chicory, and lucerne in the third production years. Mean \pm S.E. $(n=4)$.

major advantage under the relative low-input conditions. The four species chosen meets these criteria while having the potential of being productive, having a high persistence, and having a high fodder value.

\subsection{Shallow-rooted ryegrass versus the deep-rooted chicory}

Two main competitive situations can generally be expected (for review see Weiner, 1990), that is those resources can be divided symmetrically in proportion to the biomass of competing populations or asymmetrically so that the largest or strongest competitor takes relatively the most. Competition for soil resources is generally symmetric. Ryegrass increased indeed its proportion of the annual harvest herbage from $25 \%$ to $40 \%$ when improving the $\mathrm{N}$ supply. This took place on the expense of the forage legumes (Fig. 8) but surprisingly mainly on the expense of the deeper rooted lucerne (Goins and Russelle, 1996) and much less on the shallow-rooted white clover (Frame et al., 1998). This suggests an asymmetrically competitive situation that however may not be determined by root masses but determined by the heterogeneously distributed soil resources, in agreement with Schwinning (1996).

As the different legume-based crops did not differ in dry matter yield nor $\mathrm{N}$ accumulation (Fig. 1) the compensatory changes in the plant communities largely took place between chicory and the legumes (Fig. 8). One possible cause for this may be competition for incoming radiation as lucerne has an erect growth pattern compared to white clover with birdsfoot trefoil intermediate. However, this competition is not considered able to fully explain the compensatory changes in plant communities as defoliation took place relatively frequent. Another explanation may be that below-ground competition also takes place between chicory and the legumes because frequent smaller intervals of 


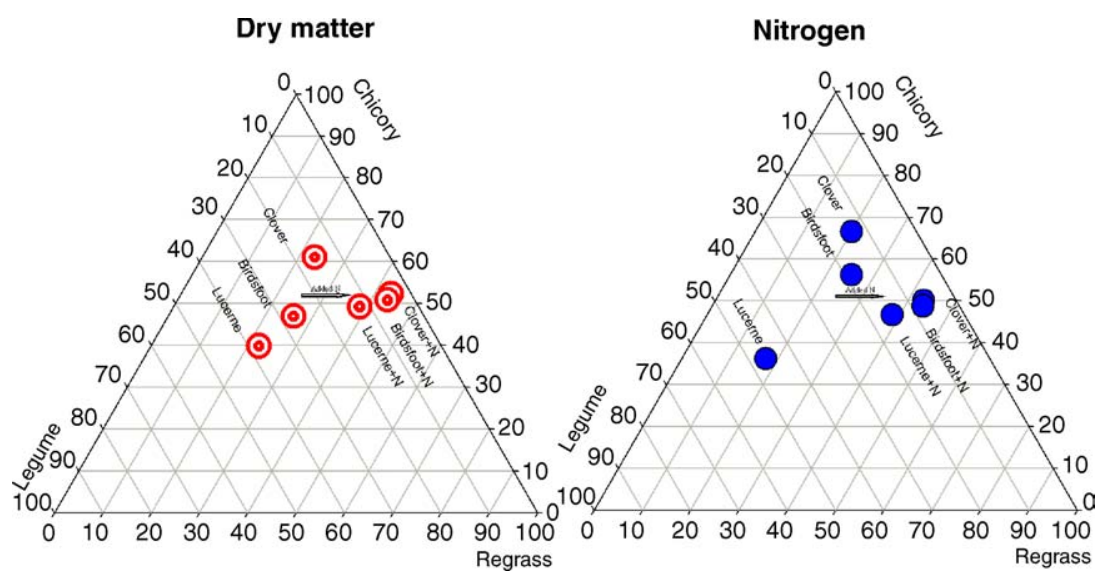

Fig. 8. Relative importance of each species in a triple grassland mixture based on dry matter and nitrogen content on annual basis. Each observation is an average from four plots under a nitrogen supply of nil or $120 \mathrm{~kg} \mathrm{~N} \mathrm{ha}^{-1} \mathrm{yr}^{-1}$.

water stress occurs under Danish conditions (Høgh-Jensen and Schjoerring, 1997; Jensen, 1996). Perennial ryegrass with its very extensive root system may be less affected by such shorter stress intervals. The high absorbance of ${ }^{15} \mathrm{~N}$ supports this possibility (Fig. 2).

\subsection{Competition or facilitation in the different pasture composition}

Legumes are generally not absorbing much of the available soil N during a growth season (Høgh-Jensen and Schjoerring, 1994, 1997; Ledgard et al., 1985). This was confirmed in this study as lucerne absorbed less than $2 \%$ of the applied ${ }^{15} \mathrm{~N}$ (Fig. 2B) leading to $\mathrm{N}_{2}$-fixation of around $98 \%$ of total plant $\mathrm{N}$ (data not shown) which is normal in low-input grassland mixtures (see review in Høgh-Jensen et al., 2004).

The traditional grassland mixture of perennial ryegrass and white clover was included in the trials to provide a kind of control. The improved supply of $\mathrm{N}$ to the swards gave as expected a small increase in the dry matter yield (Fig. 1A) but the clover content decreased and thus the total accumulation of $\mathrm{N}$ was not affected (Fig. 1B) by the soil $\mathrm{N}$ status in agreement with the internal regulatory model previous suggested (Haynes, 1980; Ledgard and Steele, 1992).

Surprisingly however was that the inclusion of chicory into the mixtures always improved the accumulation of herbage $\mathrm{N}$ substantially (Fig. 1B). This improvement was similar to the difference between pure stand ryegrass and pure stand chicory. This indicates that chicory has a substantial higher use of soil $\mathrm{N}$ sources that may not be fully available to the other species. This $\mathrm{N}$ source may be the inorganic soil $\mathrm{N}$ below the rooting zone of ryegrass as chicory was not a very good competitor for the $\mathrm{N}$ supply to the upper soil layer (Fig. 2). This improved uptake efficiency of deeper located $\mathrm{N}$ pools may give chicory a potential important role in future environmental friendly grassland farming as intensive dairy farms have an substantial $\mathrm{N}$ surplus (Halberg et al., 1995; Lantinga et al., 2004) as the higher N supplies levels in intensive systems may be expected to reduce the relative performance (Connolly et al., 2001) of even deep-rooted forage legumes as lucerne (Fig. 8).
Such a high absorbing efficiency of chicory agrees with the superior of chicory to absorb $\mathrm{N}$ that is released by ryegrass (Fig. 6B) and its relative low $\mathrm{N}$ transfer to associated species (Figs. 6, 7A and 7B). The transfer rates between chicory and ryegrass agree well with those reported by Høgh-Jensen and Schjoerring (2000). Older studies (Jones, 1943) established the concept that a large proportion of the fine roots in root systems are routinely shed which has been corroborated in recent studies (Eissenstat et al., 2000; Paolillo and Zobel, 2002). It is likely that loss of these roots enables transfer of elements after degradation. So transfer is dependent on both losses of root material, the associated species being an asymmetrically strong competitor for the released nutrients, and the roots of the associated species being able to tap the nutrients (Mårtensen et al., 1998). Xiao and Zhang (2004) established that root contact enhanced $\mathrm{N}$ transfer between species. The current data indicate that chicory is as 'contributing' as perennial ryegrass (Fig. 6A) in an unfertilised ryegrass-chicory mixture. However after further including a N-rich legume to such systems, chicory emerge as the most ' $\mathrm{N}$ conserving' of the three species (Fig. 7A). It can be speculated if the differences in rooting depth and root morphology can explain this phenomenon, e.g. contact between a tap root of chicory or lucerne (Goins and Russelle, 1996) with the dispersed shallow root system of ryegrass.

The current data shown that under the current defoliation strategy, chicory was very competitive towards white clover and birdsfoot trefoil but less towards lucerne (Fig. 8). However, chicory was found to transfer some $\mathrm{N}$ to lucerne (Fig. 6B). This support the view that all the tested species are potential contributors but it will be the most vigorous growing species in the mixture that will benefit from these traits (Figs. 6 and 7) in an asymmetrical competitive situation (Weiner, 1990).

\subsection{Herbage nutritional values}

Besides its productive (Fig. 1) and environmental qualities, chicory may have nutritional qualities (Crush and Evans, 1990). Danish organic farmers are increasingly becoming interested in supplementing their herds with chicory but so far without documentation for its effects under local conditions dominated by 
2-3 years intensive rotational grassland. Obviously the deeper rooting behaviour of chicory may give it an advantage in more permanent grassland where other grassland species permanently utilize the upper profiles permanently. Thus differences in nutritional value may occur.

Quality data has been reported for chicory in pure stands (Barry, 1998; Belesky et al., 2001; Grunes and Welch, 1989; Sanderson et al., 2003) but here we report for the first time the quality of chicory grown in field mixtures (Figs. 3-5), showing a clear time-dependency in nutrient content, in partly agreement with Belesky et al. (2001). Such time-dependent effect needs further investigations and especially their relation to soil type must be considered. Further, data is lacking on the distribution of nutrients in different organs as grazing animals may select specific plant parts. Effects of such preferential grazing may become particular important in older grassland as it may explain some of the time-dependent effects observed in this study. Nevertheless, as it may be hypothesised that the differences observed between chicory and ryegrass could be even more pronounced if the stems were not included in the calculations. This is important as ruminants tend to preferentially graze the leaves and to discharge the stems. The higher accumulation of calcium and potassium but smaller accumulation of magnesium as compared to ryegrass must also be considered as a $\mathrm{K} /(\mathrm{Ca}+\mathrm{Mg})$ ratio in excess of 2.2 (milliequivalent cation basis) especially combined with a high $\mathrm{N}$ supply, can advance grass tetany (hypo-magnesemia) in lactating dairy cattle (Grunes and Welch, 1989). The high content of zinc and copper in chicory may have a particular potential in free-range pig rearing systems as newly weaned piglets are deficient in zinc and copper (Carlson et al., 2004). There is a need for further investigations of such quality requirements in legume-based swards after inclusion of chicory.

\section{Conclusions}

The inclusion of chicory into perennial ryegrass/fodder leguminous grassland mixtures proved to be very beneficial in terms of productivity and $\mathrm{N}$ accumulation when evaluated over a 3year period. The chicory was able to utilize sub-soil $\mathrm{N}$ which may provide a management tool to improve the environmental overload on dairy farms with a high N surplus (Halberg et al., 1995). Chicory was not found to co-exist well with neighbouring leguminous species. It transferred little $\mathrm{N}$ to associated species and under favourable soil $\mathrm{N}$ conditions it almost out-competed the white clover whereas lucerne was able to withstand the competition to some degree. In mixtures with ryegrass, chicory accumulated large amounts of calcium, potassium, sodium and zinc but significant less of magnesium and manganese irrespective of the $\mathrm{N}$ supply. In the case of sodium it was a short-term effect whereas calcium and possibly also sulphur, copper and zinc accumulation increased over time.

\section{Acknowledgements}

We gratefully acknowledge financial support from the Danish Fund for Organic Agriculture, which enabled these studies. Part of this work has been supported financially by the European
Union through the project: Worm control in organic production systems for small ruminants in Europe (WORMCOPS; contract QLK5-CT 2001-1843).

\section{References}

Barry, T.N., 1998. The feeding value of chicory (Cichorium intybus) for ruminant livestock. J. Agric. Sci., Camb. 131, 251-257.

Belesky, D.P., Fedders, J.A., Turner, K.E., Ruckle, J.M., 1999. Productivity, botanical composition, and nutritive value of swards including forage chicory. Agron. J. 91, 450-456.

Belesky, D.P., Turner, K.E., Fedders, J.M., Ruckle, J.M., 2001. Mineral composition of swards containing forage chicory. Agron. J. 93, 468475 .

Boller, B.C., Nösberger, J., 1987. Symbiotically fixed nitrogen from fieldgrown white and red clover mixed with ryegrasses at low levels of ${ }^{15} \mathrm{~N}$ fertilization. Plant Soil 104, 219-226.

Carlson, D., Poulsen, H.D., Sehested, J., 2004. Influence of weaning and effect of post weaning dietary zinc and copper on electrophysiological response to glucose, theophylline and 5-HT in piglet small intestinal mucosa. Comp. Biochem. Physiol., Part A 137, 757-765.

Collins, M., McCoy, J.E., 1997. Chicory productivity, forage quality, and response to nitrogen fertilization. Agron. J. 89, 232-238.

Connolly, J., Goma, H.C., Rahim, K., 2001. The information content of indicators in intercropping research. Agric. Ecosyst. Environ. 87, 191-207.

Crush, J.R., Evans, J.P.M., 1990. Shoot growth and herbage element concentration of 'Grasslands Puna' chicory (Chicorium intybus L.) under varying soil pH. P. NZ Grassl. Assess. 51, 163-166.

Eissenstat, D.M., Wells, C.E., Yanai, R.D., 2000. Building roots in a changing environment: implications for root longevity. New Phytol. 147, 33-42.

Eriksen, J., Høgh-Jensen, H., 1998. Variation in the natural abundance of ${ }^{15} \mathrm{~N}$ in ryegrass/white clover shoot material as influenced by cattle grazing. Plant Soil 205, 67-76.

Frame, J., Charlton, J.F.L., Laidlaw, A.S., 1998. Temperate Forage Legumes. CAB International, Wallingford, UK.

Frame, J., Newbould, P., 1986. Agronomy of white clover. Adv. Agron. 40, $1-88$.

Fraser, T.J., Rowarth, J.S., 1996. Legumes, herbs or grass for lamb performance. P. NZ Grassl. Assess. 58, 49-52.

Gee, G.W., Bauder, J.W., 1986. Particle-size analysis. In: Klute, A. (Ed.), Methods of Soil Analysis, Part 1. ASA, Madison, WI, pp. 545-567.

Goins, G.D., Russelle, M.P., 1996. Fine root demography in alfalfa (Medicago sativa L.). Plant Soil 185, 281-291.

Grunes, D.L., Welch, R.M., 1989. Plant contents of magnesium, calcium, and potassium in relation to ruminant nutrition. J. Anim. Sci. 67, 3485-3494.

Halberg, N., Kristensen, E.S., Kristensen, I.S., 1995. Nitrogen turnover on organic and conventional mixed farms. J. Agric. Environ. Ethics 8, 30-51.

Haynes, R.J., 1980. Competitive aspects of the grass-legume association. Adv. Agron. 33, 227-261.

Høgh-Jensen, H., Schjoerring, J.K., 1994. Measurement of biological dinitrogen fixation in grassland: comparison of the enriched ${ }^{15} \mathrm{~N}$ dilution and the ${ }^{15} \mathrm{~N}$ natural abundance method at different nitrogen application rates and defoliation frequencies. Plant Soil 166, 153-163.

Høgh-Jensen, H., Schjoerring, J.K., 1997. Interactions between white clover and ryegrass under contrasting nitrogen availability: $\mathrm{N}_{2}$ fixation, $\mathrm{N}$ fertilizer recovery, N transfer and water use efficiency. Plant Soil 197, 187-199.

Høgh-Jensen, H., Schjoerring, J.K., 2000. Below-ground nitrogen transfer between different grassland species: direct quantification by ${ }^{15} \mathrm{~N}$ leaf feeding compared with indirect dilution of soil ${ }^{15} \mathrm{~N}$. Plant Soil $227,171-183$.

Høgh-Jensen, H., Loges, R., Jørgensen, F.V., Vinther, F.P., Jensen, E.J., 2004. An empirical model for quantification of symbiotic nitrogen fixation in grass-clover mixtures. Agric. Syst. 82, 181-194.

Jensen, S.E., 1996. Agroclimate at Taastrup 1961-1990. Jordbrugsforlaget, Copenhagen.

Jones, F.R., 1943. Growth and decay of the transient (noncambial) roots of alfalfa. J. Am. Soc. Agron. 35, 625-634 
Jung, G.A., Shaffer, J.A., Varga, G.A., Everhart, J.R., 1996. Performance of 'Grassland Puna' chicory at different management levels. Agron. J. 88, 104-111.

Komolong, M., Nicol, A.M., Poppi, D.P., Fraser, T.J., Kirsopp, S., 1992. Nutrient supply for lamb growth from Grassland Puna chicory (Cichorium intybus) and Wana cocksfoot (Dactylis glomerata). P. NZ Soc. Anim. Prod. 52, 85-87.

Lantinga, E.A., Oomen, G.J.M., Schiere, J.B., 2004. Nitrogen efficiency in mixed farming systems. J. Crop Improv. 12, 437-455.

Ledgard, S.F., Simpson, J.R., Freney, J.R., Bergersen, F.J., 1985. Field evaluation of ${ }^{15} \mathrm{~N}$ techniques for estimating nitrogen fixation in legume-grass associations. Aust. J. Agric. Res. 36, 247-258.

Ledgard, S.F., Steele, K.W., 1992. Biological nitrogen fixation in mixed legume/grass pasture. Plant Soil 141, 137-153.

Mårtensen, A.M., Rydberg, I., Vestberg, M., 1998. Potential to improve transfer of $\mathrm{N}$ in intercropped systems by optimising host-endophyte combinations. Plant Soil 205, 57-66.

Paolillo Jr., D.J., Zobel, R.W., 2002. The formation of adventitious roots on root axes is a widespread occurrence in field-grown dicotyledonous plants. Am. J. Bot. 89, 1361-1372.
Peoples, M.B., Faizah, A.W., Rerkasem, B., Herridge, D.F., 1989. Methods for Evaluating Nitrogen Fixation by Nodulated Legumes in the Field. ACIAR, Canberra, p. 72.

Rumball, W., 1986. Grasslands Puna chicory (Cichorium intybus L.). NZ J. Exp. Agric. 14, 105-107.

Sanderson, M.A., Labreveux, M., Hall, M.H., Elwinger, G.F., 2003. Nutritive value of chicory and English plantain forage. Crop Sci. 43, 17971804.

SAS Institute, 1993. SAS/STAT Software: Syntax Version 6, 1st ed. SAS Institute Inc., Cary, NC.

Schwinning, S., 1996. Decomposition analysis of competitive symmetry and size structure dynamics. Ann. Bot. 77, 47-57.

Turner, K.E., Belesky, D.P., Fedders, J.A., 1999. Chicory effects on lamb weight gain and rate of in vitro organic matter and fiber disappearance. Agron. J. 91, 445-450.

Weiner, J., 1990. Asymmetric competition in plant populations. Trends Ecol. Evol. 5, 360-364.

Xiao, Y., Zhang, F., 2004. Effect of root contact on interspecific competition and $\mathrm{N}$ transfer between wheat and fababean using direct and indirect ${ }^{15} \mathrm{~N}$ techniques. Plant Soil 262, 45-54. 